\title{
Pengaruh Gaya Kepemimpinan Kepala Sekolah Terhadap Kinerja Guru Pada SMA Adzkia Islamic School
}

\author{
Bachtiar Arifudin Husain \\ Dosen Fakultas Ekonomi Universitas Pamulang \\ Email : dosen01773@unpam.ac.id
}

\begin{abstract}
ABSTRAK
Tujuan penelitian ini adalah untuk mengetahui gaya kepemimpinan kepala sekolah dan kinerja guru serta untuk mengetahui pengaruh gaya kepemimpinan terhadap kinerja guru pada SMA Adzkia Islamic School.

Metode penelitian yang digunakan dalam penelitian ini adalah penelitian kuantitatif, teknik pengumpulan data dalam penelitian ini dengan menggunakan teknik kuesioner, data yang diperoleh dari kuesioner yang berjumlah 50 responden kemudian di analisis dan diberikan pembobotan nilai dengan menggunakan skala likert dan menggunakan bantuan Microsoft Office dan rumus-rumus statistik dengan metode uji validitas, uji realibilitas, korelasi product moment, koefisien determinasi, uji regresi linier sederhana, dan uji hipotesis.

Hasil penelitian menunjukan bahwa gaya kepmimpinan kepala sekolah pada SMA Adzkia Islamic School sudah dinilai baik. Hal ini dilihat dari total rata-rata variabel sebesar 3,94 yang berada pada skala interval 4,15. Begitupun degan Kinerja Guru pada SMA Adzkia Islamic School sudah dinilai tinggi. Hal ini dilihat dengan total rata-rata variabel sebesar 4,04 yang berada pada skala interval 4,19. Dengan menggunakan regresi linier sederhana $\mathrm{Y}=\mathrm{a}+\mathrm{bx}$, dengan nilai $\mathrm{Y}=24.82$ dan $\mathrm{X}=0.40$, korelasi product moment didapat nilai $r_{x y}$ sebesar 0.466 , hal ini menunjukan bahwa nilai korelasi antara gaya kepemimpinan kepala sekolah dan kinerja Guru Pada SMA Adzkia Islamic School adalah baik. Dan dari hasil pengujian hipotesis didapatkan nilai $t_{\text {hitung }}$ lebih besar dari $t_{\text {tabel }}(3,225>2,010)$, maka Ho ditolak dan Ha diterima sehingga dapat disimpulkan bahwa terdapat pengaruh positif dan signifikan gaya kepemimpinan Kepala Sekolah dan kinerja Guru pada SMA Adzkia Islamic School. Dan dari perhitungan koefisien determinasi diatas diperoleh dari nilai $17.80 \%$. Hal ini menunjukan bahwa pengaruh gaya kepemimpinan Kepala Sekolah terhadap kinerja Guru pada SMA Adzkia Islamic School yakni sebesar $17.80 \%$, sedangkan sisanya $82.20 \%$ dipengaruhi oleh faktor lainnya.
\end{abstract}

\section{Kata Kunci : Gaya Kepemimpinan Kepala Sekolah dan Kinerja Guru}




\section{PENDAHULUAN}

\section{Latar Belakang}

Pembukaan

Undang-

Undang Dasar Negara Republik Indonesia Tahun 1945 menyatakan bahwa tujuan nasional adalah untuk melindungi segenap bangsa dan seluruh tumpah darah Indonesia dan untuk memajukan kesejahteraan umum, mencerdaskan kehidupan bangsa, dan ikut melaksanakan ketertiban dunia berdasarkan kemerdekaan perdamaian abadi, dan keadilan sosial. Untuk mewujudkan tujuan nasional tersebut, pendidikan merupakan faktor yang sangat menentukan. Pasal 31 UndangUndang Dasar Negara Republik Indonesia Tahun 1945 mengamanatkan bahwa setiap warga negara berhak mendapat pendidikan, Setiap warga negara wajib mengikuti pendidikan dasar dan pemerintah wajib membiayainya, Pemerintah mengusahakan dan menyelenggarakan satu sistem pendidikan nasional yang meningkatkan keimanan dan ketaqwaan serta akhlak mulia dalam rangka mencerdaskan kehidupan bangsa, yang diatur dengan undang-undang, dan Pemerintah memajukan ilmu pengetahuan dan teknologi dengan menjunjung tinggi nilai-nilai agama dan persatuan bangsa untuk kemajuan peradaban serta kesejahteraan umat manusia. Menurut Amin Kuneifi Elfachmi (2015:13) Pendidikan adalah usaha untuk mendapatkan pengetahuan, baik secara formal melalui sekolah maupun secara informal dari pendidikan di dalam rumah dan masyarakat.

Guru merupakan komponen yang paling berpengaruh terhadap terciptanya proses dan hasil pendidikan yang berkualitas. Oleh karena itu upaya perbaikan apapun yang dilakukan untuk meningkatkan kualitas pendidikan tidak akan memberikan sumbangan yang signifikan tanpa di dukung oleh guru yang profesional dan berkualitas. Tugas guru erat kaitannya dengan peningkatan sumber daya manusia melalui sektor pendidikan, oleh karena itu perlu upaya-upaya untuk meningkatkan mutu guru untuk menjadi tenaga profesional. Agar peningkatan mutu pendidikan dapat berhasil dan hendaknya mampu meningkatkan kesempatan belajar bagi siswa. Sebagaimana dikemukakan oleh Drs.Moh.Uzer Usman (2012:7) peningkatan kualitas pendidikan tergantung banyak hal, terutama mutu gurunya. Namun demikian mutu guru akan berkaitan dengan banyak hal, diantaranya kepemimpinan kepala sekolah, budaya organisasi, dan motivasi kerja guru yang bersangkutan.

Pertumbuhan sekolah modern berbasis Islam cukup menggembirakan. Perpaduan kurikulum sekolah formal dengan metode pembelajaran berbasis pesantren mulai dipercaya masyarakat. Namun, tak jarang muncul suara-suara kritikan jika sekolah modern berbasis Islam mahal dalam pembiayaan.

Tantangan sekolah modern berbasis pesantren dan terjangkau dijawab oleh Adzkia Islamic 
School. Terletak di pinggiran Jakarta Selatan, tepatnya Ciputat, Tangerang Selatan, Adzkia Islamic School membebaskan semua biaya sekolah bagi anak didiknya.

SMA Adzkia Islamic School didirikan pada 23 Februari 2007 oleh Yayasan Daarut Tauhiid yang dipimpin oleh KH Abdullah Gymnastiar (Aa Gym).

Gaya kepemimpinan merupakan suatu pola perilaku para pemimpin dalam mengarahkan dan mengendalikan para bawahan untuk mengikuti kehendaknya dalam mencapai suatu tujuan dan sasaran yang telah ditetapkan. Secara sederhana dapat dikatakan bahwa kepemimpinan merupakan cara yang dipergunakan oleh seorang pemimpin dalam mempengaruhi bawahannya. Cara dalam mempengaruhi bawahannya akan menciptakan budaya dari organisasi yang dipimpinnya.

Gaya Kepemimpinan seseorang tidak semata hanya ditentukan oleh kelebihanya secara fisik seperti badan yang besar tetapi lebih ditentukan cara atau gaya orang itu memimpin atau mempengaruhi

bawahannya. Berhasil atau tidaknya seseorang memimpin dengan gaya yang dimilikinya tentu juga tidak terlepas dari faktor lain seperti tingkat pendidikan, minat, motivasi, semangat, kedisiplinan, tingkat usia, jenis kelamin, tingkat kecerdasan, tingkat emosi, sarana yang tersedia, situasi/kondisi, tingkat ekonomi, lingkungan dan sebagainya. Dari sekian banyak faktor yang mendukung keberhasilan seorang pemimpin, penulis dalam penelitian ini akan mengangkat permasalahan dimana kepemimpinan dipengaruhi oleh kecerdasan emosi, dan cara memimpin disekolah yang terkadang tidak mau diberi masukan dan saran oleh bawahannya, ada kalanya seorang pemimpin memberikan perintah berdasarkan hal - hal yang sifatnya subjektif atau lebih ditonjolkan yang pribadi. Bawahan atau orang yang dipimpin juga sering tidak dapat menerima kebijakan yang dibuat pimpinan karena faktor yang sifatnya pribadi, cenderung berprasangka buruk terhadap kebijakan yang dibuat. Kepemimpinan kepala sekolah selain dipengaruhi oleh gaya kepemimpinan juga dipengaruhi oleh berbagai kecerdasan seperti kecerdasan emosi, sehingga gaya kepemimpinan yang tepat bila diikuti dengan kecerdasan emosi yang baik akan menghasilkan kinerja yang baik dan aspek kinerja guru merupakan aspek penting yang perlu diperhatikan.

Berkaitan dengan kinerja guru, wujud untuk kerja yang dimaksud adalah berkaitan dengan kegiatan guru dalam proses pembelajaran, yaitu bagaimana guru merencanakan pembelajaran, melaksanakan kegiatan pembelajaran, dan menilai serta mengevaluasi hasil belajar.

Kinerja guru tidak terlepas dari peran seorang Kepala Sekolah sebagai pimpinan yang mempunyai wewenang untuk memerintah orang lain, kepala sekolah berperan aktif menyelesaikan persoalan - 
persoalan yang timbul dari bawahannya dan itu sekaligus tantangan yang harus dihadapi oleh seorang pimpinan karena itu kepala sekolah senantiasa menghadapi dan mengarahkan semua kekuatannya untuk memecahkan persoalan pada bawahannya, akan tetapi upaya yang dilakukan seorang kepala sekolah tidak semudah yang kita pikirkan kepala sekolah terkendala oleh banyak hal seperti sikap bawahan/guru dalam menafsirkan perintah yang diberikan oleh pimpinan dalam hal ini kepala sekolah, sering kita menemukan ada kalanya terjadi kontradiksi kemauan antara pimpinan dan bawahan, antara guru dan kepala sekolah, apa yang diinginkan kepala sekolah tidak dapat ditangkap atau diterima oleh guru sehingga menimbulkan prasangka.

Pimpinan yang baik dalam menjalankan kepemimpinannya merupakan point di mana organisasi ingin meningkatkan dan mengembangkan knowledge dan ability individu.

Berdasarkan uraian tersebut, penelitian bermaksud untuk mengetahui seberapa besar pengaruh gaya kepemimpinan kepala sekolah terhadap kinerja guru pada SMA Adzkia Islamic School, yang mendorong peneliti untuk melakukan penelitian dengan judul "Pengaruh Gaya Kepemimpinan Kepala Sekolah Terhadap Kinerja Guru Pada Sma Adzkia Islamic School".

\section{Perumusan Masalah}

Dari identifikasi yang telah penulis kemukakan, maka penulis akan merumuskan permasalahan sebagai berikut :

a. Bagaimana gaya kepemimpinan kepala sekolah pada SMA Adzkia Islamic School?

b. Bagaimana kinerja guru pada SMA Adzkia Islamic School?

c. Bagaimana pengaruh gaya kepemimpinan kepala sekolah terhadap kinerja guru pada SMA Adzkia Islamic School?

\section{Tujuan Penelitian}

a. untuk mengetahui gaya kepemimpinan kepala sekolah pada SMA adzkia islamic school.

b. untuk mengetahui kinerja guru pada SMA adzkia islamic school.

c. untuk mengetahui pengaruh gaya kepemimpinan kepala sekolah terhadap kinerja guru pada SMA adzkia islamic school.

\section{TINJAUAN PUSTAKA}

\section{Gaya Kepemimpinan}

Gaya kepimimpinan menurut Hasibuan (2014:170) adalah cara seorang pemimpin mempengaruhi perilaku bawahan, agar mau bekerja sama dan bekerja secara produktif untuk mencapai tujuan organisasi.

Kepala Sekolah sebagai pemimpin pendidikan, di lihat dari status dan cara pengangkatan tergolong pemimpin resmi, formal leader, atau status leader. Status leader bisa meningkat menjadi functional leader. Tergantung dari prestasi dan kemampuan didalam memainkan peranannya sebagai pemimpin pendidikan sebagai 
sekolah yang telah diserahkan pertanggung jawaban kepadanya.

\section{Kinerja Guru}

Kinerja (performance)
menurut Bangun (2013:231)
adalah hasil pekerjaan yang
dicapai seseorang berdasarkan
persyaratan-persyaratan pekerjaan
(job requirement). Kinerja
merupakan suatu kegiatan yang
dilakukan untuk melaksanakan,
menyelesaikan tugas dan tanggung
jawab sesuai dengan harapan dan
tujuan yang telah ditetapkan
Supardi (2014:45).

Kinerja sering disebut dengan prestasi yang merupakan hasil atau apa yang keluar (outcomes) dari sebuah pekerjaan dan kontribusi sumber daya manusia terhadap organisasi.

\section{METODE PENELITIAN}

Metode penelitian yang digunakan dalam penelitian ini adalah penelitian kuantitatif, teknik pengumpulan data dalam penelitian ini dengan menggunakan teknik kuesioner, data yang diperoleh dari kuesioner yang berjumlah 50 responden kemudian di analisis dan diberikan pembobotan nilai dengan menggunakan skala likert dan menggunakan bantuan Microsoft Office dan rumus-rumus statistik dengan metode uji validitas, uji realibilitas, korelasi product moment, koefisien determinasi, uji regresi linier sederhana, dan uji hipotesis.

\section{HASIL DAN PEMBAHASAN}

\section{Regresi Linier}

Analisis koefisien regresi digunakan untuk mengetahui pengaruh antara variabel $\mathrm{X}$ yaitu Gaya kepemimpinan terhadap variabel Y yaitu Kinerja guru pada SMA Adzkia Islamic School.

Dengan demikian dapat diperoleh angka persamaan berdasarkan dari output coefficients $\mathrm{Y}=24.82+0.40 \mathrm{X}$. Dari persamaan terlihat bahwa koefisien $b$ bernilai Positif, ini menunjukkan bahwa perubahan $\mathrm{Y}$ searah dengan perubahan $\mathrm{X}$. Jadi nilai $\mathrm{Y}$ akan meningkat jika $\mathrm{X}$ meningkat, sebaliknya nilai $\mathrm{Y}$ akan menurun jika $\mathrm{X}$ menurun. Jadi dapat disimpulkan bahwa Gaya kepemimpinan kepala sekolah berpengaruh positif terhadap Kinerja guru pada SMA Adzkia Islamic School, artinya jika Gaya kepemimpinan kepala sekolah diterapkan dengan baik maka akan meningkatkan Kinerja guru, begitu pula sebaliknya. Koefisien regresi $\mathrm{X}=0.40$, maka skor variabel $\mathrm{Y}$ akan bertambah 1 point dengan asumsi konstanta 24.82 poin.

\section{Analisis Koefisien Korelasi}

Setelah seluruh instrument yang digunakan penulis lakukan pengujian validitas dan realibilitas dan dinyatakan valid dan reliabel. Langkah selanjutnya adalah melakukan analisis koefisien korelasi. Analisis koefisien korelasi dimaksudkan untuk mengatur keeratan hubungan (korelasi) antara dua variabel. Yaitu variabel gaya kepemimpinan kepala sekolah terhadap kinerja guru.

Interval koefisien yang berada dalam nilai $0,600-0,799$ adalah tingkat hubungannya kuat. Sehingga, dilihat dari perbandingan antara hasil korelasi sebesar 0,466 dengan ketentuan 
nilai interval koefisien yang ditetapkan tersebut dapat disimpulkan bahwa korelasi antara variabel $\mathrm{X}$ dan variabel $\mathrm{Y}$ adalah cukup kuat.

\section{Koefisien Determinasi}

Dimana ketentuan untuk mengetahui adanya korelasi, jika nilai koefisien determinasi semakin mendekati 1 maka semakin besar pula pengaruh di antara varibel $\mathrm{X}$ dan variabel $\mathrm{Y}$.

$\mathrm{KD}=\mathrm{r}^{2} \times 100 \%$

$=(0,422)^{2} \times 100 \%$

$=0,1780 \times 100 \%$

$=17,80 \%$

Dilihat dari nilai koefisien determinasi yang didapatkan dan ketentuan tersebut, maka dapat disimpulkan bahwa adanya kontribusi di antara Gaya Kepemimpinan Kepala Sekolah (X) dan Kinerja Guru (Y).

Dimana,

koefisien determinasi yang diperoleh sebesar $17,80 \%$ hal ini menunjukan bahwa besarnya kontribusi gaya kepemimpinan kepala sekolah terhadap kinerja guru adalah sebesar $17,80 \%$ sedangkan sisanya $(100 \%-17,80$ $\%)=82,20 \%$ di pengaruhi faktor lain yang tidak diteliti.

\section{Uji Hipotesis}

Berdasarkan

hasil perhitungan di atas, maka penulis melakukan pengujian hipotesa dengan cara membandingkan nilai $\mathrm{t}$ tabel dengan $\mathrm{t}$ hitung. Nilai $\mathrm{t}$ tabel ditentukan berdasarkan tingkat signifikan $(\alpha)$ yang digunakan dan derajat kebebasan $(\mathrm{df}=\mathrm{n}-2)$ yang besarnya tergantung dari jumlah sampel (n). Taraf nyata yang penulis gunakan sebesar 0.05 (5\%).
Rumus $t$ hitung adalah sebagai berikut :

$$
\begin{aligned}
\mathrm{t} & =\frac{r \sqrt{n-2}}{\sqrt{1-\mathrm{r}^{2}}} \\
& =\frac{0.422 \sqrt{50-2}}{\sqrt{1-0.422^{2}}} \\
& =\frac{0.422 \sqrt{48}}{\sqrt{1-0.1780}} \\
& =\frac{0.422 \cdot 6.928}{0.907} \\
& =\frac{2.923}{0.907} \\
& =3.225
\end{aligned}
$$

Dari perhitungan di atas, maka diperoleh $\mathrm{t}$ hitung sebesar 3.225 dan $t$ tabel dapat dilihat pada lampiran adalah sebesar 2.010.Sehingga, dapat disimpulkan bahwa data yang terjadi pada objek penelitian dengan data yang dilaporkan oleh peneliti adalah signifikan karena nilai $\mathrm{t}$ hitung lebih besar daripada $\mathrm{t}$ tabel yaitu 3.225>2.010 yang telah ditetapkan yang artinya Jika $t_{\text {hitung }}$ $\geq$ dari $\mathrm{t}_{\text {tabel }}, \mathrm{H}_{0}$ ditolak $; \mathrm{H}_{1}$ diterima (signifikan).

\section{PENUTUP}

\section{Kesimpulan}

Dari hasil penelitian yang telah peneliti lakukan maka peneliti memberikan kesimpulan sebagai berikut :

a. Gaya Kepemimpinan Kepala Sekolah SAM Adzkia Islamic School penulis menyimpulkan berdasarkan hasil jawaban seluruh responden yang berjumlah 50 orang bahwa saat ini pada kategori baik. Hal ini dibuktikan dengan nilai ratarata tertinggi dengan nilai 4,15 pada indikator gaya 
kepemimpinan delegatif, hal ini berarti bahwa kepala sekolah bertindak sebagai fasilitator terhadap para guru dan menyerahkan tanggung jawab penuh terhadap para guru sesuai dengan jabatannya masingmasing dalam menyelesaikan suatu pekerjaan (Hal:73).

b. Kinerja Guru pada SMA Adzkia Islamic School penulis menyimpulkan berdasarkan hasil jawaban seluruh responden yang berjumlah 50 orang bahwa saat ini pada kategori tinggi. Hal ini dibuktikan dengan nilai ratarata tertinggi dengan nilai 4,19 pada indikator komunikasi, hal ini berarti bahwa guru mampu mengkomunikasikan hal- hal baru dalam pembelajaran serta melakukan layanan bimbingan dan arahan kepada siswa dan siswi dengan baik (Hal:75).

c. Pengaruh Gaya Kepemimpinan Kepala Sekolah terhadap Kinerja Guru pada SMA Adzkia Islamic School berdasarkan hasil penelitian menunjukan persamaan regresi linear sederhana $\mathrm{Y}=\mathrm{a}+\mathrm{bx}$, dengan nilai $Y=24.82$ dan $\mathrm{X}=0.40 \mathrm{X}$ artinya bahwa koefisien $b$ bernilai positif, ini menunjukan bahwa perubahan $\mathrm{Y}$ searah dengan perubahan $\mathrm{X}$. Jadi nilai $Y$ akan meningkat jika $\mathrm{X}$ meningkat, sebaliknya nilai $\mathrm{Y}$ akan menurun jika $\mathrm{X}$ menurun. Nilai koefisien korelasi sebesar 0,466 dengan ketentuan nilai interval koefisien yang ditetapkan tersebut dapat disimpulkan bahwa korelasi antara variabel
$\mathrm{X}$ dan variabel $\mathrm{Y}$ adalah kuat. Dan dari perhitungan koefisien determinasi diatas diperoleh dari nilai $17.80 \%$. Hal ini menunjukan bahwa pengaruh gaya kepemimpinan Kepala Sekolah terhadap kinerja Guru pada SMA Adzkia Islamic School yakni sebesar $17.80 \%$, sedangkan sisanya $82.20 \%$ dipengaruhi oleh faktor lainnya.dari hasil pengujian hipotesis didapatkan nilai thitung lebih besar dari ttabel $(3,225>2,010)$, maka Ho ditolak dan Ha diterima sehingga dapat disimpulkan bahwa terdapat pengaruh positif dan signifikan gaya kepemimpinan Kepala Sekolah dan kinerja Guru pada SMA Adzkia Islamic School.

\section{Saran}

Berdasarkan analisis yang dilaksanakan dan tertuang dari beberapa bab dalam penelitian dan hasil kesimpulan yang telah dijelaskan sebelumnya, maka peneliti mencoba menuangkan beberapa saran yang bermanfaat bagi peningkatan kinerja kerja pada guru.

a. Dari hasil jawaban kuesioner untuk variabel gaya kepemimpinan kepala sekolah rata-rata terkecil dengan nilai 3,74 pada variabel (X) yaitu indikator gaya kepemimpinan kharismatik, hal ini berarti bahwa kepala sekolah harus lebih menginspirasi untuk bawahannya, serta harus menjadi panutan bawahannya (Hal:73).

b. Dari hasil jawaban kuesioner untuk variabel kinerja guru rata- 
rata terkecil dengan nilai 3,66 pada variabel (Y) yaitu indikator kualitas kerja, ini artinya bahwa guru harus lebih berinovasi dalam perencanaan program pengajaran dan penilaian hasil belajar (Hal:76).

c. Bagi peneliti selanjutnya, dapat dikembangkan dengan mengetahui gaya kepemimpinan kepala sekolah dan kinerja guru terdapat pengaruh positif, ini artinya bahwa gaya kepemimpinan kepala sekolah sudah dapat diterima dengan baik oleh para guru.

\section{DAFTAR PUSTAKA}

AA. Anwar Prabu Mangkunegara. 2014. "Manajemen Sumber Daya Manusia Perusahaan".Penerbit Remaja Rosdakarya, Bandung.

Abdurrahman, Maman dan Sambas Ali Muhidin. 2011. "Panduan Praktis Pemahaman Penelitian (Bidang Sosial-AdministrasiPendidikan)". Bandung: CV Pustaka Setia.

Arikunto, Suharsimi. 2013. "Prosedur Penelitian Suatu pendekatan Praktek". Penerbit Rineka Cipta, Jakarta.

B. Uno, Hamzah 2015. "Teori Motivasi dan Pengukurannya Analisis Di Bidang Pendidikan". Jakarta: Bumi Aksara.

Bangun. Wilson. 2015. "Manajemen Sumber Daya Manusia". Penerbit Erlangga, Bandung.

Basyiruddin Usman. 2016. "Media Pendidikan”. Penerbit Ciputat Pres, Jakarta.
Cascio, Wayne F. 2015. "Managing Human Resources”. New York: The McGrawHill Companies.

Elfachmi, Kuneifi Amin. 2015. "Penghantar Pendidikan". Jakarta. Erlangga.

Fandy Tjiptono, 2006."Manajemen Pelayanan Jasa". Penerbit Andi, Yogyakarta.

Gibson, James, L.John M, Ivancevich dan James H. Donnelly, Jr. 2014. "Organizations dan Manajemen". Jakarta: PT. Gelora Aksara Pratama.

Gouzali Saydam. 2014. "Manajemen Sumber daya Manusia: Suatu pendekatan". Mikro,

Gujarati, D. N. 2013. "Dasar-dasar Ekonometrika”. Edisi Kelima. Mangunsong, R. C., penerjemah. Jakarta: Salemba Empat.

Guritno, Bambang dan Waridin. 2005. "Pengaruh Persepsi Karyawan Mengenai Perilaku Kepemimpinan, Kepuasan Kerja dan Motivasi Terhadap Kinerja”. Jurnal Riset Bisnis Indonesia Vol.1 No.1, p. 63-74.

Hasibuan, Malayu. 2016. "Manajemen Sumber Daya Manusia”. Penerbit. PT Bumi Aksara, Jakarta.

Husein Umar. 2013. "Metode Penelitian untuk Skripsi dan Tesis". Jakarta: Rajawali.

Husein, Umar. 2014. "Riset pemasaran dan bisnis". Gramedia Pustaka Utama, Jakarta.

J. Supranto, 2014. "Statistik Teori dan Aplikasi". Edisi ketujuh Jilid 2: Jakarta, Penerbit Erlangga.

Nawawi, Ismail. 2013. "Budaya organisasi kepemimpinan dan 
Kinerja”. Jakarta: PT. Fajar Iterpratama Mandiri.

Nazir, Moh. 2015. "Metode Penelitian". Penerbit Ghalia Indonesia, Bogor.

Rivai, Veitzhal dan Mulyadi, Deddy. 2014. "Kepemimpinan dan Perilaku Organisasi”. Jakarta: PT Raja Grafindo Persada.

Robbins, Stephen P. 2015. "PrinsipPrinsip Perilaku Organisasi”. Penerbit Erlangga, Jakarta.

Supardi U .2015. “Arah Pendidikan di Indonesia dalam Tataran Kebijakan dan Implementasi”. Jakarta : Bumi Aksara.

Sarwono, Jonathan dan Tutty Martadiredja. 2012. "Riset Bisnis Untuk Pengambilan Keputusan".'Yogyakarta : Andi Offset.

Simamora, Henry. 2014. "Manajemen Sumber Daya Manusia”. Yogyakarta: Bagian Penerbitan Sekolah Tinggi Ilmu Ekonomi YKPN.

Sugiyono. 2015. "Metode Penelitian Pendidikan Pendekatan
Kuantitatif, kualitatif, dan $R \& D ”$ Penerbit Alfabeta, Bandung.

Sunyoto, Danang. 2015. "Manajemen dan Pengembangan Sumber Daya Manusia"(Cetakan Pertama). Yogyakarta: CAPS (Center for Academic Publishing Service).

Supardi. 2014. "Kinerja Guru”. Penerbit PT Raja Grafindo Persada, Jakarta.

Terry, George R dan Rue, Leslie W. 2015.

"Dasar-dasar manajemen”. Cetakan ke 16. Jakarta. PT. Bumi Aksara.

Uzer Usman, Moh. (2015). "Menjadi Guru Profesional”. Bandung: Remaja Rosdakarya.

W. Gulo. 2014. "Metodelogi Penelitian".Penerbit Grasindo, Jakarta.

Yamin, Martinis \& Maisah 2013. "Manajemen Pembelajaran Kelas: Strategi Meningkatkan Mutu Pembelajaran". Jakarta: GP Press. 